\title{
Back to School: Upskilling Teachers' Competence through Online Scholarship Workshop
}

\author{
Yogi Saputra Mahmud ${ }^{1 *}$, Richard Kuhon², Donald Samuel Slamet Santosa ${ }^{3}$, Ani \\ Pujiastuti $^{4}$ iD \\ ${ }^{1}$ President University, Bekasi, Indonesia \\ *Corresponding author: yogi.saputra@president.ac.id
}

\begin{abstract}
Abstrak
Sebagai salah satu upaya mengembangkan kompetensi dan karir, Pendidikan tinggi dinilai penting untuk dimiliki oleh setiap orang, termasuk untuk para pengajar. Akan tetapi, kemampuan finansial dapat menjadi salah satu hambatan utama bagi para pengajar dalam mengenyam Pendidikan tinggi, terutama di luar negeri. Di sisi lain, Pemerintah Indonesia melalui mekanisme beasiswa pendidikan Lembaga Pengelola Dana Pendidikan (LPDP) memberikan kesempatan untuk warga negara Indonesia untuk mengenyam Pendidikan tinggi dengan bantuan pembiayaan Pendidikan. Di saat yang sama, berbagai mekanisme beasiswa pun ditawarkan oleh berbagai badan, seperti Australia Awards, Chevening, Fulbright, DAAD, dsb. Oleh karena itu, program pengabdian masyarakat ini bertujuan untuk meningkatkan pemahaman para guru-guru sekolah, mahasiswa program studi Pendidikan, serta masyarakat umum akan persiapan administratif dan teknis beasiswa. Selain itu, para peserta juga diharapkan dapat memiliki pemahaman akan situasi akademik dan sosial saat studi di luar negeri, serta pengaruhnya terhadap karir saat pasca studi. Terdapat total 535 peserta yang terdiri dari guru sekolah, mahasiswa prodi Pendidikan, dan masyarakat umum lainnya dari berbagai penjuru wilayah Indonesia yang mengikuti kegiatan lokakarya ini. Hasil kegiatan ini menunjukkan bahwa ada $112(47,5 \%)$ peserta yang memberikan nilai maksimal untuk tingkat relevansi workshop online dengan kondisi mereka saat ini. Persentase peserta yang tinggi $(33,9 \%)$ juga memberikan tanggapan positif terhadap relevansi online.
\end{abstract}

Kata Kunci: Beasiswa, Guru, Lokakarya, LPDP

\section{Abstract}

As an effort to develop competencies and careers, higher education is considered important for everyone, including teachers. However, the financial ability can be one of the main obstacles for teachers in pursuing higher education, especially abroad. On the other hand, the Government of Indonesia through the educational scholarship mechanism, the Education Fund Management Institute (LPDP) provides opportunities for Indonesian citizens to receive higher education with education funding assistance. At the same time, various scholarship mechanisms are offered by various bodies, such as Australia Awards, Chevening, Fulbright, $D A A D$, etc. Therefore, this community service program aims to increase the understanding of school teachers, students of Education study programs, and the general public regarding the administrative and technical preparation of scholarships. In addition, the participants are also expected to have an understanding of academic and social situations while studying abroad, as well as their impact on careers while post-study. There were a total of 535 participants consisting of school teachers, students of the Education study program, and other general public from various parts of Indonesia who participated in this workshop. The results of this activity showed that there were 112 (47.5\%) participants who gave the maximum value for the level of relevance of the online workshop to their current condition. A high percentage of participants (33.9\%) also gave a positive response to online relevance.

Keywords: Scholarship, Teacher, Workshop, LPDP

$\begin{array}{lll}\text { History: } & & \text { Publisher: Undiksha Press } \\ \text { Received } & \text { : 2 January } 2021 & \text { Licensed: This work is licensed under } \\ \text { Revised } & : \text { 23 January } 2021 & \text { a Creative Commons Attribution 3.0 License } \\ \text { Accepted } & : \text { O6 February } 2021 & \text { CC (O) } \\ \text { Published } & : \text { 25 February } 2021 & \end{array}$




\section{Introduction}

Professional development is deemed to be an integrated part of developing the career and competence of teachers. In this regard, career or professional development is usually oriented to the development of organisations or companies facing various business challenges in the future. Career is a series of activities and traits related to practices, attitudes, values, and aspirations throughout one's life (Hani Handoko, 2016; Rachman, 2009). Career or professional development is incredibly essential for practitioners in an organisation since it can improve individual and organisational performance in any industry (Permatasari, 2017). For academicians, human resources (HR) improvement can be conducted through career and professional development. There are three fundamental competences of competent human resources: (1) the ability to master various branches of technology and knowledge, (2) the ability to work professionally and independently, and (3) the ability to create excellent works. These three aspects should be developed continuously by maintaining the culture, characteristics, and values of Indonesian people (Suryadi, 2012). The management of academic quality can be conducted by improving the education level to a higher level in the best public or private universities in Indonesia or overseas (Mahmud, 2020). This effort becomes more complicated because of decentralisation policy in Indonesian education (Kuhon, 2020).

One strategic way to build their competence and professionalism is by pursuing an academic degree overseas to enhance their pedagogical (Santosa \& Irawati, 2018), social, and cultural competencies. Scholars have conducted massive studies on professional development internationally (Bautista \& Ortega-Ruiz, 2015; Lam, 2015; Niemi, 2015). The majority of teachers' professional development studies are dedicated to teachers and teachers training institutions (Avalos, 2011; Desimone, 2009). In the context of the Indonesian higher education landscape, having a doctorate degree allows academicians more likely to be promoted for managerial positions in their organisations. This makes pursuing a degree at a higher level of education one of the stimuli for faculty members with master's degrees to advance their qualifications. Although the definitions of early-career academicians may vary in other countries (Bosanquet et al., 2017), in Indonesia, most of the lecturers and researchers in higher education institutions have not earned doctorate degrees, which could be a significant impediment to organisational and academic productivity functions. This is relevant in most cases because for some early career academicians, status and promotion are considered as criteria that define success in academic settings (Sutherland, 2017). One of the programs carried out is to provide scholarships to academics who want to develop their careers.

In general, scholarship refers to students' financial assistance to pursue a higher degree covering financial needs throughout their academic journey. In other words, it relates to the assistance offered to individuals to complete their education to gain knowledge entirely without having to face any financial constraint. This assistance is usually given in a certain amount of funds to support their educational expenses during their journey at the university or other academic institutions. A scholarship is defined as a financial reward from governmental institutions, enterprises, and other organisations given to individuals to support their academic journey (Lahinta and Wardoyo (2014). The scholarship is deemed to have an essential role in developing professionalism for individuals by completing a higher degree. Through scholarship schemes, individuals will have more accessibility to pursue a higher degree in the desired university since the scholarship scheme will cover the expenses, such as tuition fees, living costs, travel costs, and other costs. In addition, the scholarship program also supports the individuals by providing various professional developments, such as Nation Building, Character Building, Leadership Development, Competition Challenges, and 
International Exposure, that will be valuable for the development of the individuals' career. There are various types of scholarships with various benefits offered to the applicants. Furthermore, multiple institutions like governmental institutions, private enterprises, and foundations also provide scholarships for students or professionals to develop the quality of education and support the individuals' rights to obtain education and career developments.

However, it is quite difficult for practitioners or academics to obtain information about preparation for carrying out career development programs in the current condition. For example, career or professional development can be conducted through pursuing a higher degree. Limited information, access or network, forum, and financial capacity can be significant obstacles to continuing academic studies. Moreover, the spread of COVID-19 in Indonesia and other parts of the world dramatically impacts various aspects, such as the economic crisis, closure of access to flights and transportation (travel ban), social and physical distancing policies, and many others. Recent research has highlighted the significant impact of the COVID-19 pandemic on individual career development (Akkermans et al., 2020; Guan et al., 2020; Oleschuk, 2020). Consequently, it can prevent academics from maximising their preparation to pursue a higher degree through various scholarship schemes, including LPDP scholarship.

Based on the following statement, the Primary School Teacher Education (PSTE) study program, President University, initiated a community empowerment program in the form of an online workshop and seminar entitled Back to School: Upskilling Teachers' Competence through Scholarship Programs. In this program, we partnered with The Indonesian Endowment Fund for Education or Lembaga Pengelola Dana Pendidikan (LPDP), invited school teachers and student teachers to give more specific information and training regarding the scholarship schemes, particularly related to the Education field. The objectives of the current community empowerment program are as follows: 1) Explore opportunities for school teachers and student teachers to improve their competence through scholarship programs offered by various organisations; 2) Explore the best practices for teachers to prepare for their academic journey in the future; and 3) Establish a networking platform for scholarship recipients, President University scholars, stakeholders, as well as education communities. This community empowerment program was expected to be able to provide advantages and outcomes for the participants, as stated in the following points: 1) Participants were able to engage with various opportunities in developing their competence through the information and exposure of the scholarship program in Indonesia or overseas; 2) Participants were able to comprehend strategic ways to prepare for their academic trajectory in the future. And 3) Participants were able to develop their academic and social networks with scholarship recipients, academicians, stakeholders, and education communities.

\section{Materials and Methods}

Due to the spread of COVID-19 since March 2020, this community empowerment program was conducted online in the form of online workshops and seminars. Regarding this, the committee decided to utilise the Zoom application to enable participants up to 1,000 to join the program. In terms of the program preparation, the committee submitted a proposal to President University Research and Community Service Institute to conduct the online workshop. In relation to the publication and registration of the event, the committee published and announced the events in various social media accounts, such as the Primary School Teacher Education study program Instagram account, the Center of Language and Culture account, and other education-related Instagram accounts. Moreover, the committee also invited the school teachers directly through email to participate in this community empowerment program. 
Furthermore, this community empowerment program also invited main presenters to provide information and workshops during this event, including Ir. Dwi Larso, Ph.D. as the Scholarship Director at LPDP, and three LPDP scholarship recipients from three different countries: Yogi Saputra Mahmud (Monash University, Australia), Richard Kuhon (University College London, Inggris), and Athina Sakina Ratum (University of Groningen, Belanda). Following this, the committee also informed the technicalities to all presenters regarding the timeframe of the workshop, main materials, and the platform used for the online workshop. Participants registered to the event through Google Forms. In this registration form, the participants also received some information related to the link of the Zoom conference for the event, attendance form, as well as feedback questionnaire. Once the participants completed the feedback questionnaire, they would automatically receive the event eCertificate to their email. Ultimately, the committee sent a reminder mail one or two days prior to the event to remind the participants about the community empowerment program.

\section{Resul and Disscusion}

This community empowerment program was conducted on Monday, 31 August 2020 through the Zoom application. There were 535 participants in total who came from all over the regions in Indonesia in this program. In regards to the program materials, Ir. Dwi Larso, $\mathrm{Ph}$.D. outlined the primary information related to LPDP scholarship in the year 2020 and 2021, particularly for the teachers who are interested in pursuing a higher degree to upskill their competence and career through the Beasiswa Pendidik scheme. Moreover, he also elaborated that the organisation would prioritise the scholarship scheme for medical practitioners and teachers/educators. This is caused by the urgency of managing the COVID19 pandemic and administering online learning activities to all students in Indonesia. Therefore, through this project, the project participants can do strategic planning to pursue a higher degree abroad through the LPDP scholarship scheme, mainly Beasiswa Pendidik.

Following this, Ani Pujiastuti, M.A Ph.D. as the head of the Primary School Teacher Education study program at President University, emphasised the importance of pursuing a higher degree for teachers to develop a sense of professionalism among the teachers in Indonesia. With the emergence of the LPDP scholarship program, it is expected that the teachers can maximise such opportunities to develop their career and competence. After the information was delivered by the Scholarship Director of LPDP and the chief of the study program, all the LPDP scholarship recipients from three different countries delivered the main workshop and seminar. In this regard, Yogi Saputra Mahmud (Monash University) shared the information about administrative, substantive, and technical preparation to register for the LPDP scholarship. This material is considered essential for the participants in order to maximise their preparation in the selection of the LPDP scholarship scheme for teachers. In the next session, Richard Kuhon (University College London) outlined his experience during his academic journey in the United Kingdom. This material is considered important to provide specific insights related to academic and non-academic transitions that would be faced by the teachers when they study overseas. In addition, he also shared the importance of balancing academic and non-academic activities to maintain the prospective students' mental health. In the last session, Athina Sakina Ratum (University of Groningen) exemplified the impact of pursuing a higher degree overseas towards the development of her career as a lecturer at President University. She also explained the effect of working and studying ethics experienced in the Netherlands towards her role as a teaching staff at President University.

After the material session, participants were given opportunities to ask questions during this community empowerment program. Regarding this, participants were able to discuss directly with the presenters through live chat in the Zoom application or directly talk 
to the presenters. The questions being asked by the participants were mainly related to the administrative and technical preparation for the LPDP scholarship scheme. Furthermore, some other participants also enquired about the impact of pursuing a higher degree in their career development as a teacher or lecturer after completing the study. The community empowerment program entitled Back to School: Upskilling Teachers' Competence through Scholarship Programs was completed by the discussion and suggestion from each presenter, as well as the expectation that participants could start preparing for LPDP scholarship selection in order to enjoy the opportunity to develop their competence and career by pursuing a higher degree overseas. The moderator then requested the participants to complete the evaluation questionnaire to be able to receive the eCertificate of the program.

\section{Discussion}

After completing the workshop, the committee invited all participants to complete a post-workshop questionnaire through Google Form. From 535 total participants who participated in the workshop and seminar, there were 236 participants who completed the questionnaire distributed by the committee. This questionnaire was distributed to discover the participants' attitudes and perspectives toward the community empowerment program. In general, it was discovered that participants responded positively toward this workshop and seminar. As can be seen in Figure 1, more than half of the participants who filled in the questionnaire gave the maximum point for their satisfaction level toward the event. Furthermore, $34.7 \%$ of the participants also gave 4 of 5 for their overall satisfaction toward the workshop and seminar. Moreover, participants also reported that the online workshop provided to them is considered highly relevant to their current situation and condition, as can be seen in the following Figure 2.

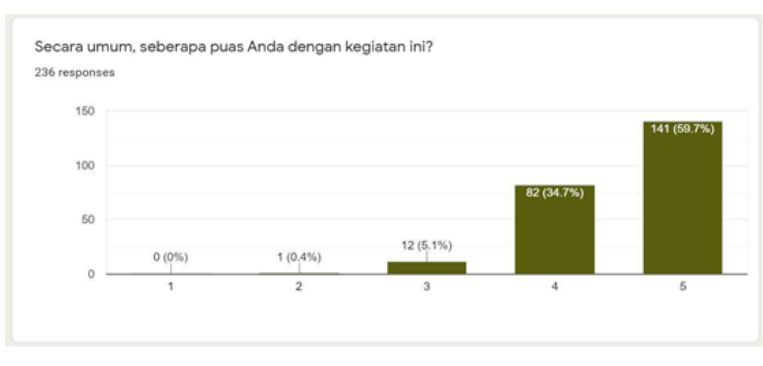

Figure 1. The overall response of the participants toward the workshop

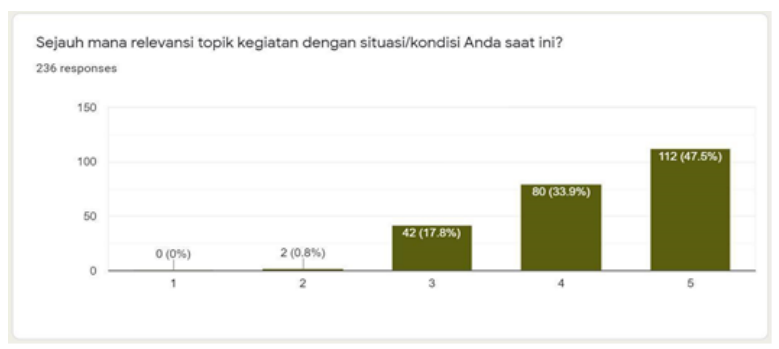

Figure 2. The relevance level of the online workshop to the participants' condition

As can be seen in the above figure, there were 112 (47.5\%) participants who gave the maximum point for the relevance level of the online workshop to their current condition. A high percentage of participants $(33.9 \%)$ also put a positive response to the relevance of the online workshop to their present situation with 4 of 5 points. Several studies have discovered the importance of scholarship workshop toward university students as the participants of the program (Saputra et al., 2020; Wirawan, 2019). For instance, Saputra et al. (2020), who conducted a scholarship webinar to university students in Papua, revealed that the participants responded positively to the event as it can enhance their motivation to pursue a higher degree through financial aid provided by the government through LPDP. In a similar vein, Wirawan (2019), who conducted a community program for university students in Kalimantan, emphasises the importance of scholarship workshop to enrich the students' understanding regarding strategies to get the scholarship, improve the English language, as well as the motivation to study in a higher degree. 
Regarding the aspects of the workshop being conducted, the participants were asked to give their responses to four aspects, including the workshop material, the selection of presenters, the workshop platform, as well as the question and answer session. As can be identified in Figure 3, participants gave positive responses to the four workshop aspects in general. More specifically, the selection of presenters and presentation materials became the two highest preferred aspects of the workshop. The presenters in this workshop were carefully selected in order to cover the general objectives of the workshop. Regarding this, the presenters had distinct backgrounds from one to another that also represented three different study destinations: Australia, The United Kingdom, and The Netherlands. Meanwhile, presentation materials were designed to allow the participants to practice for themselves after the workshop was complete. Therefore, it is assumed that the participants were satisfied with the aforementioned aspects because of the reasons.

The participants were also asked to put their responses regarding the presentation materials in this workshop. As stated in the previous section, there were three main materials in this presentation or workshop, including pre-scholarship that covers main materials related to the preparation of scholarship registration in terms of administrative and technical preparation, while scholarship covers the main activities and experiences while studying overseas, post scholarship covers the discussion on the impacts of pursuing a higher degree towards the future development of career and competence. In Figure 4 below, participants reported that pre-scholarship and while scholarship becomes the two most relevant materials for them. Consequently, it was assumed that the preparation of scholarship registration is strongly needed by the participants. Furthermore, the participants were also eager to discover the academic and non-academic experiences while studying overseas. This finding is considered relevant with a community program conducted by Saputra et al. (2020), who conducted a scholarship workshop partnered with LPDP to Papuan students in order to enhance the students' understanding and awareness of the scholarship opportunities. Saputra et al. (2020) also discovered that the participants were highly passionate about the scholarship session, motivating them to pursue a higher degree overseas with funding assistance from the Indonesian government.

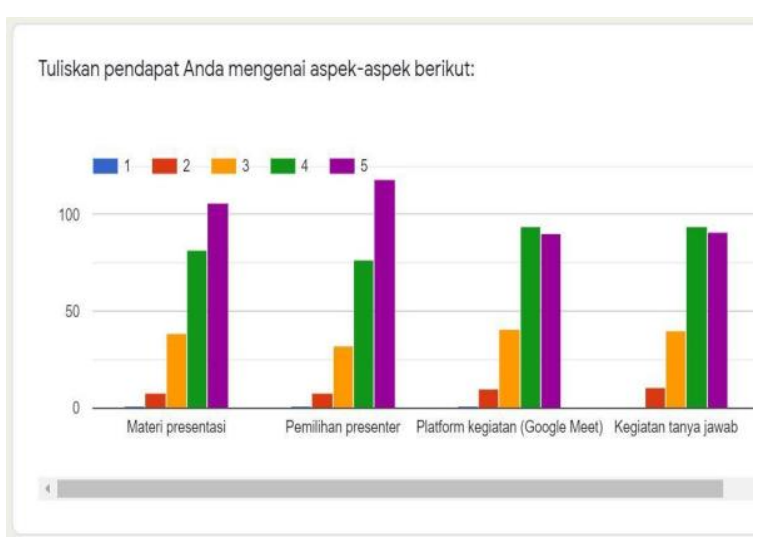

Figure 3. Participants responses toward the workshop aspects

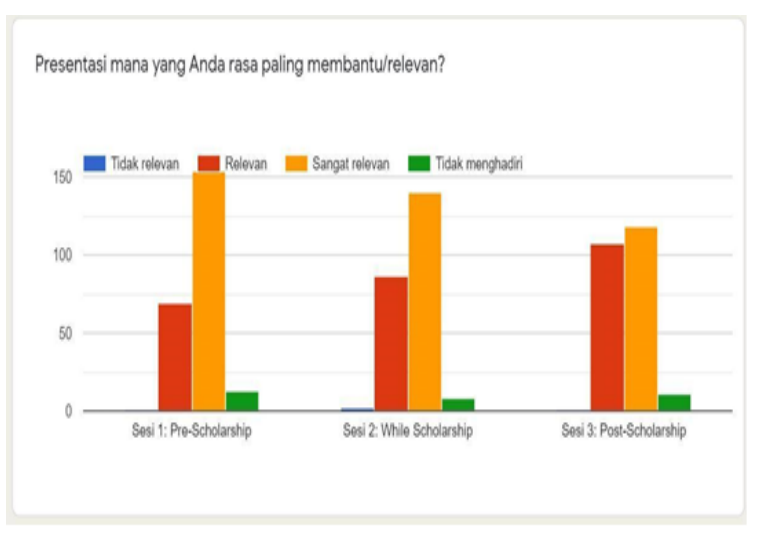

Figure 4. Participants responses toward the presentation materials

\section{Conclusion}

This community empowerment program attempts to enlighten teachers and student teachers' understanding and awareness of developing competence and career through a scholarship program. It is expected that the participants, including schoolteachers, student teachers, and other education communities, can benefit from this online workshop. For 
further development of this community empowerment program, it is strongly suggested that future stakeholders enlighten the teachers in terms of practical understanding, such as writing a motivation letter, study plan, research proposal, and many others. Ultimately, the future program should also involve a higher number of participants to extend the beneficence of the program.

\section{References}

Akkermans, J., Richardson, J., \& Kraimer, M. L. (2020). The Covid-19 crisis as a career shock: Implications for careers and vocational behavior. In Journal of Vocational Behavior (Vol. 119, p. 103434). Academic Press Inc. https://doi.org/10.1016/j.jvb.2020.103434.

Asmawi, M. R. (2005). Strategi meningkatkan lulusan bermutu di perguruan tinggi. Makara Human Behavior Studies in Asia, 9(2), 66. https://doi.org/10.7454/mssh.v9i2.124.

Avalos, B. (2011). Teacher professional development in Teaching and Teacher Education over ten years. In Teaching and Teacher Education (Vol. 27, Issue 1, pp. 10-20). Pergamon. https://doi.org/10.1016/j.tate.2010.08.007.

Bautista, A., \& Ortega-Ruiz, R. (2015). Teacher professional development: International perspectives and approaches. Psychology, Society and Education, 7(3), 343-355. https://doi.org/10.25115/psye.v7i3.514.

Bosanquet, A., Mailey, A., Matthews, K. E., \& Lodge, J. M. (2017). Redefining 'early career' in academia: a collective narrative approach. Higher Education Research and Development, 36(5), 890-902. https://doi.org/10.1080/07294360.2016.1263934.

Desimone, L. M. (2009). Improving impact studies of teachers' professional development: Toward better conceptualizations and measures. Educational Researcher, 38(3), 181199. https://doi.org/10.3102/0013189X08331140.

Guan, Y., Deng, H., \& Zhou, X. (2020). Understanding the impact of the COVID-19 pandemic on career development: Insights from cultural psychology. In Journal of Vocational Behavior (Vol. 119, p. 103438). Academic Press Inc. https://doi.org/10.1016/j.jvb.2020.103438.

Hani Handoko. (2016). Manajemen personalia dan sumberdaya manusia. Universitas Pelita Bangsa.

Kuhon, R. R. (2020). Decentralisation and education for all in Indonesia. Polyglot: Jurnal Ilmiah, 16(1), 14. https://doi.org/10.19166/pji.v16i1.1996.

Lahinta, A., \& Wardoyo, R. (2014). Sistem pendukung keputusan penentuan penerima beasiswa :: Studi kasus pada TPSDM Propinsi Gorontalo. [Yogyakarta] : Universitas Gadjah Mada.

Lam, B. H. (2015). Teacher professional development in Hong Kong compared to anglosphere: The role of confucian philosophy. Psychology, Society and Education, 7(3), 295-310. https://doi.org/10.25115/psye.v7i3.521.

Mahmud, Y. S. (2020). Investigating early-career teachers' adaptation challenges: A case of Indonesian EFL Teachers. PROJECT (Professional Journal of English Education), 3(3), 367. https://doi.org/10.22460/project.v3i3.p367-378.

Mudahkan akses pendidikan, Pemerintah siapkan beasiswa S2 dan S3. (2014).

Nawawi, H. (2006). Manajemen sumber daya manusia untuk bisnis yang kompetitif. Gadjah Mada University Press.

Niemi, H. (2015). Teacher professional development in Finland: Towards a more holistic approach. Psychology, Society and Education, 7(3), 279-294. https://doi.org/10.25115/psye.v7i3.519.

Oleschuk, M. (2020). Gender equity considerations for tenure and promotion during COVID-19. Canadian Review of Sociology/Revue Canadienne de Sociologie, 57(3), 
502-515. https://doi.org/10.1111/cars.12295.

Perlu sinergi dunia usaha-pemerintah dalam pendidikan tinggi. (2011, December). Kompas.Com.

Permatasari, I. R. (2017). Pengaruh pengembangan karir terhadap kinerja karyawan.

Rachman, W. (2009). Evaluasi kinerja sumberdaya manusia. Salemba Empat.

Samsudin, S. (2006). Manajemen sumber daya manusia. Pustaka Setia.

Santosa, D. S. S., \& Irawati, L. (2018). Kompetensi pedagogik guru SMP Negeri 2 Kaloran Kecamatan Kaloran Kabupaten Temanggung. Jurnal Ecodunamika, 1(2), 1-12.

Saputra, D., Said, E., \& Maipauw, N. J. (2020). Peran pendidikan di era milenial. Abdimas: Papua Journal of Community Service, 2(1), 18-22.

Sistem pendidikan kebidanan di Indonesia. (2012).

Standar dosen pendidikan tinggi vokasi tenaga kesehatan. (2013).

Suryadi, A. (2012). Pendidikan, investasi SDM, dan pembangunan. isu, teori dan aplikasi untuk pembangunan, pendidikan dan sumberdaya manusia Indonesia. Widya Aksara Press.

Sutherland, K. A. (2017). Constructions of success in academia: an early career perspective. Studies in Higher Education, 42(4), 743-759. https://doi.org/10.1080/03075079.2015.1072150.

Wirawan, R. (2019). Mendorong peningkatan daya saing sumber daya manusia kalimantan timur melalui seminar beasiswa wish festival \& education expo. PLAKAT (Pelayanan Kepada Masyarakat), 1(1), 27-37. 